\title{
REPRESENTATION OF EXPERIENCE IN SUSILOBAMBANG YUDHOYONO'S SPEECH
}

\author{
Oleh: \\ Rahmat Huda /NIDN 0131129001 \\ Program Studi Pendidikan Bahasa Inggris UMTS Padangsidimpuan
}

Email: rahmad.huda@um-tapsel.ac.id

\begin{abstract}
The study presents a research conducted of Experiential Function in Susilo Bambang Yudhoyono's speech at the Asia Pacific Regional Conference of Open Government Partnership (OGP) which hold in Nusa Dua Bali. The main objective found the dominant pattens of representation of experience formed by transitivity (process, participant and circumtance) and described of situational contexts (arena, participant's characteristics and semantic domain). It presented a qualitative design dealing with quantifiable (numeric) mode. The source of the data was taken from the opening speech of Susilo Bambang Yudhoyono on May 6, 2014. The data were collected by applying documentary technique. The data analysis found out the findings that there were five types of process from six types of process (material, mental, relational, behavioural, verbal and existential). The patterns of each process were different from others, namely material patterns 59 (55.67\%), mental 19 $(17.92 \%)$, relational; identification $3(2.83 \%)$, attribution $10(9.43 \%)$, possession $7(6.60 \%)$, verbal $5(4.71 \%)$ and exsistential $3(2.83 \%)$. The percentage shows that the dominant patterns are formed by material process. Whereas, the behaviuoral pattern related to pshyological and psychological did not find in the speech. Meanwhile, the context of situation of the speech tend to the field and dominated by arena or social activity which refers to the location where social activities were performed, especially [+institutionalized].
\end{abstract}

Keywords: Experiential function, Speec

\section{INTRODUCTION}

Language users enables to conceptualize and describe patterns of experience which was encoded in the clause as representation (experiential function) and dealt with the types of processes, the participants and circumstances associated with them. A study on language based on the Systemic Functional Linguistics (SFL) is oriented to the description of language as a resource for meaning rather than as a system of rules and to the speakers' meaning potential (what they can mean) rather than the constraints on what they can say. It is concerned with text rather than sentences as the basic unit in which meaning is negotiated. It treats grammar as the realization of discourse, naturally related to its semantics. In modelling language as systems of meaning potential, choices becomes the basis for language use. Not only is language in use or text 
shaped by choice, it is also influenced by social context of situation and culture.

Halliday's Functional Grammar is a tool to explore the specific type of linguistic choices that are used for some specific purposes. Systemic Functional Grammar deals with three major functions; Ideational, interpersonal and textual. Ideational functions allow the user to convey the meanings with an understanding of the context, community and material world. Interpersonal functions of language illustrate the connection between the sender and the receiver through different angles, while Textual functions refer to the internal formation and association of a text.

The ideational function is the content function of language. It is realized in transitivity and serves to represent situations and events in the world and the entities, actions and process involved. It is in the ideational function that the textproduces embodies in language their experience of the phenomena of the real world.

Transitivity system fits into experiential metafunction of language and explores the variation of experience. It works within clause level and each clause determines its following components, such; process, participant and circumtance.

Halliday suggested six types of process and Martin, Matthiessen and
Painter (1997) elaborated them in detail in their book "Working with Functional Grammar". They further describe them and specify their participants, they are: material, mental, relational, behavioural, verbal and exitential.

The context of situation which obtains through a systematic relationship between the social environment on the one hand, and the functional organization of language on the other. Language as a tool to express views and notions. Most of the politicians use language to spread a specific ideology. A politician usually employs various process to achieve his/her purpose. It becomes almost a rule that at least one process dominates in a particular discourse due to the particular register it belongs to.

\section{RESEARCH METHOD}

\section{Research Design}

The researcher uses a descriptive qualitative design, because it explains the data systematically, factually and accurately (Issac and Michael, 1971:42). According to Ary (2010:29) there are many different types of qualitative research; we consider briefly eight of the most widely used approaches: (1) basic interpretative studies, (2) case studies, (3) document or content analysis, (4) ethnography, (5) grounded theory, (6) historical studies, (7) narrative inquiry and (8) phenomenological studies. 
The writer applied basic interpretative studies provides descriptive accounts targeted to understanding a phenomenon using data that might be collected in a variety of ways such as interviews, observations, and document review. The purpose is to understand the world of experience of another.

As already noted, this study is one part of qualitative research namely document or content analysis. The material that is used is public records that is SBY's speech at the Asia-Pacific Regional Conference of Open Government Partnership. This study described the findings of the patterns of representation in the speech and in what context the way it is. To support the explanation of the data and to give description clearly about the pattern in representation of experience in SBY speech. The researcher also presents the frequency of the process and circumstance element that appear in the speech.

\section{Data and Source of the Data}

The data of this research are clauses found in SBY's speech which downloaded from internet. The data downloaded in original form. Then, the researcher did not need to transcribe the utterances from the speech. The data source of this research is SBY's speech in the opening ceremonial at the Asia-Pacific Regional Conference of Open
Government Partnership (OGP) which hold from 6-7 May 2014 in Nusa Dua Bali-Indonesia.

\section{Technique of Collecting Data}

The most common data collection methods used in qualitative research are: (1) observation, (2) interviewing, and (3) document or artifact analysis. Artifacts may include audion and video recordings, photographs, games, artwork, or other items that provide insight related to the context or participants. (Ary, 2010:431)

Firstly, observation is a basic method for obtaining data in qualitative research and is more than "hanging out". The qualitative researcher's goal is a complete description of behaviour in a specific setting rather than a numeric ummary of occurence or duration of observed behaviours. Qualitative observation is more likely to proceed without any prior hyphoteses. Qualitative observation rely on narrative or words to describe the setting, the behaviours, and the interactions. The goal is to understand complex interactions in natural settings.

Secondly, interviews are used to gather data from people about opinions, beliefs, and feelings about situations in their own words. They are used to help understand the experiences people have and the meaning they make of them rather than to test the hypotheses. The structure 
of the interview follows the extent to which th questions to be asked are developed prior to the interview. In the qualitative approcah, the list of questions is generlly more limited in lenght and most questions cannot be answered with yes or no or limited word responses.

Thirdly, document and artifacts. Qualitative researchers may use written documents or other artifacts to gain an understanding of the phenomenon under study. The term documents here refers to a wide range of written, physical, and visual materials. Documents may be personal, such as autobiographies, diaries and letters;official, such as files, reports, memoranda, or minutes, or documents of popular culture, such as books, films and videos.

Fourthly, document analysis can be written or text-based artifacts (textbooks, novels, journals, meeting minutes, logs, announcements, policy statements, newspapers, transcripts, birth certificates, marriage records, budgets, letters, e-mail messages, etc). Or non written records (photographs, audiotapes, videotapes, computer images, websites, musical performance, YouTube videos, virtual world settings, televised political speeches, etc).

As already mentioned, this study were gathered the data by using documentary technique. Because the data of the study is written or text based, especially transcript of the political speech by SBY at the Asi Pacific Regional Confrence of Open Government artnership (OGP). It means that through documentary technique, the data were collected by reading and studying some books and references related to the study.

\section{Instrument of Collecting Data}

One of the distinguishing characteristics of qualitative research is the methods used to collect and analyze data. In qualitative study, the human investigator is the primary instrument for ghatering and analzying of data.

$$
\text { Lincoln and Guba (1985) }
$$

introduced the concept of human as instrument to emphasize the unique role that qualitative researchers play in their inquiry. Because qualitative research studies human experiences and situations, researchers need an instrument flexible enough to capture the complexity of human experience, an instrument capable of adapting and responding to the environment.

Whereas, Bogdan an Biklen (1992) stated that "the researcher is the key instrument." It means that everything which is related to this resarch controlled by the researcher.

While Sugiono (2008) stated that "instrument in naturalistic inquiry is the human." In this study, the key instrument of the research is the researcher himself. 
He reads the document and written record as qualitative inquiry relies on fieldwork methods, especially document analysis.

This research took the SBY's speech as source of data and applied experiential function to analyze the data, to find and to elaborate the patterns of representation in the speech and it what context it was. Another instruments that used by the researcher to gather the data are notebook (to downloaded the data), and phone (using the hotspot connection that connected to the notebook to download), printer (to print the data out), etc.

\section{Technique of Analyzing Data}

In analyzing the data, there are some procedures based on experiential function as follows: (1) Separating the text into clauses, (2) Analyzing each clause in terms of the experiential function, (3) Identifying the types of process and circumtance in the speech, (4) Identifying the pattern of experiential function element in the speech, (5) Identifying the most dominant pattern used in the speech, (6) Elaborating some reasons for the most dominant pattern used in the speech.

(Saragih, 2012:39-40)

\section{FINDINGS AND DISCUSSIONS}

\section{Data}

The data of the research were clauses found in Susilo Bambang Yudhoyono's speech at the Asia Pacific Regional Conference of Open Government
Partnership (OGP) hold in Nusa Dua Bali on May 6-7, 2014. The speech especially delivered in the opening of the conference at the first day, namely on May 6 .

\section{Data Analysis}

Representation of the speech realized by applying experiential function in analyzing the data. It analyzed based on Halliday's theory. The realizations were elaborated by analyzing the patterns which formed by transitivity system, namely process, participant and circumtance.

There are six (6) types of process used in the speech such as material, mental, relational, behavioural, verbal and existential. Meanwhile, there are seven (9) types of circumtances such as extent, location, manner, cause, contingency, accompaniment, role, matter and angel.The proportion of the process and circumtances used in the speech ummarized in the table 4.2 and 4.3 , which is obtained by using the pattern introduced by Bungin (2005:171), namely;

$$
\text { Types of process }=\frac{F x}{N} \times 100
$$

Where

$F x=$ individual frequency (one type of process) $N=$ total number (all types of process) 
The results of the calculations of process types are summarized in the table 4.2

Table 4.2 Proportion of process types and its percentage

\begin{tabular}{clcc}
\hline No $_{0}$ & Types of process $^{*}$ & Number of process & Percentage \\
\hline 1 & Material & 59 & $55.67 \%$ \\
2 & Mental & 19 & $17.92 \%$ \\
3 & Relational & & \\
& a. Identification & 3 & $2.83 \%$ \\
& b. Attribution & 10 & $9.43 \%$ \\
& c. Possession & 7 & $6.60 \%$ \\
4 & Behavioural & - & - \\
5 & Verbal & 5 & $4.71 \%$ \\
6 & Existential & 3 & $2.83 \%$ \\
\hline & Total & $\mathbf{1 0 6}$ & $\mathbf{1 0 0 \%}$ \\
\hline
\end{tabular}

* Types of process related to the patterns

From the table 4.2 can be seen that the number of material; 59 (55.67\%), mental ; 19 (17.92\%), relational; 20 and divided into three; identification; 3 (2.83\%), attribution; $10 \quad(9.43 \%)$, possession; 7 (6.60\%), behavioural process; 0 (0\%), verbal; $5(4.71 \%)$, and existential; $3(2.83 \%)$. It means that the dominant is material process, they were 59 process $(55.67 \%)$.

Futhermore, there are 9 types of circumtances found in SBY's speech at the Asia-Pacific Regional Conference of Open Government Partnership. They are extent, location, manner, cause, contingency, accompaniment, role, matter and angle.

The results of the calculations of circumtances types are summarized in the table 4.3

\begin{tabular}{|c|c|c|c|}
\hline $\mathbf{N}_{0}$ & Iypes of process* & Number of circumtances & Percentage \\
\hline \multirow[t]{3}{*}{1} & Extent & & \\
\hline & Temporal (duration) & 4 & $430 \%$ \\
\hline & Syalìal (distance) & 0 & $0 \%$ \\
\hline \multirow[t]{2}{*}{2} & Location & & \\
\hline & $\begin{array}{l}\text { Temporal (time) } \\
\text { Spatial (place) }\end{array}$ & $\begin{array}{c}15 \\
5\end{array}$ & $\begin{array}{l}16.13 \% \\
538 \%\end{array}$ \\
\hline 3 & Manner & 28 & $30.10 \%$ \\
\hline 4 & Causc & 2 & $215 \%$ \\
\hline 3 & Contingency & 0 & $045 \%$ \\
\hline 6 & Accompaniment & 15 & $16.13 \%$ \\
\hline 7 & Role & 8 & $860 \%$ \\
\hline 8 & Matter & 1 & $108 \%$ \\
\hline \multirow[t]{2}{*}{9} & Angle & $\mathrm{g}$ & $968 \%$ \\
\hline & Total & 93 & $100 \%$ \\
\hline
\end{tabular}

From the table 4.3 can be seen that the number of circumtances extent (temporal:duration) is $4(4.30 \%)$, extent (spatial:distance) is $0(0 \%)$, location (temporal:time) is $15(16.13 \%)$, location (spatial:place) is $5(5.38 \%)$, manner is 28 $(30.10 \%)$, cause is $2(2.15 \%)$, contingency is $6(6.45 \%)$, accompaniment is 15 $(16.13 \%)$, role is $8(8.60 \%)$, matter is 1 $(1.08 \%)$ and angle is 9 (9.68). It means that the dominant is circumatance of manner, they were $28(30.107 \%)$.

\section{Findings}

After the data divided into the clauses, there were found one hundred six (106) of clauses. The clauses were analyzed by applying experiential function and displaying the pattern which was formed by transitivity (process, participant and circumtance). The patterns were coded by types of process, namely material, mental, relational, behaviuoral, verbal, and existential. But, in this research the findings only found five (5) patterns; material, mental, relational, verbal, and existential.

The number of the patterns were different one pattern from other patterns: (1) the total number of material patterns were 35 from 59 patterns, they were at the clause; $6,7,9,11,15,16,18,23,24,26 b$, 28, 29, 30, 33, 34, 39, 40, 41, 43, 44, 47, $48,49,51 b, 53,55,56,57,58,60,62,63$, 64, 66, 69, 70, 71, 73, 74, 77, 80, 83, 85, $87,88,89,93,95,96 b, 97 b, 98,99,101$, 
103, 104, 105, 106. (2) mental patterns were 6 from 19 patterns, they were at the clause; 1, 2, 8, 16a, 19a, 38, 46a, 50,54, 59a, 59b, 84b, 91, 94, 96, 97, 99b, 100, 102. (3) relational patterns were 14 from 20 patterns, they were at the clause; $42 \mathrm{~b}$, 45, 46b, 47b, 50b, 51, 52, 61, 65b, 66b, $67,68,76,78,79,82,84,89 b, 90,92$. (4) verbal patterns were five from 5 patterns, they were at the clause; 42a, 65, 81, 86, 91b. (5) existential patterns were 2 from 3 , they were at the clause; $13,17$.

In other words, the political issues are affective to the use of material process or in this case material pattern. This is to say that due the persuade another countries joining the program the text required dominantly used of material process (material pattern). Meanwhile, the behavioural patterns did not find in the speech. It based on the definition of behavioural process. Behavioural process is the process of phsyological and phsycological behaviour namely breathing, dreaming, snoring, smiling, watching, listening, etc.

There were no single word that has been mentioned in the speech, because to determined the types of process were realized by realization of the process itself. It means that the typical of process realized by verbal group and the processes are central of transitivity or obligatory. Therefore, the context of situation of the speech affected by field. It deterministics to the use of the element of experiential function and dominated by arena, especially [+institutionalized] or social activity refers to the location where social activities were performed. It is analyzed that all text are about politics and they are related to persuade another countries joining to Open Government Partnership (OGP).

\section{Discussions}

Based on data analysis and findings, it can be seen that the dominant were material patterns, the patterns were 35 from 59 patterns and the pattern clauses or a half from the total number of the clauses found in SBY's speech. Material process is known as process of doing which related to the verb of the sentence. The common examples of verbs used in the material process namely: have successfully brought, shows, began, include, determined, etc.

Semantically, material pattern indicate activities or event which happen in the outside world. That is why material pattern is the dominant in Susilo Bambang Yudhoyono's speech at the Asia Pacific Regional Conference of Open Government Partnership (OGP) in 2014. It means that SBY wants to tell all countries joining the program to fight political issues like: promote transparency, empower citizen, fight corruption and harness new technology. 
Therefore, SBY dominantly used the participant "I" in the speech. For example it can be taken from clause number 1, 6 and 8, namely; (1) At the outset, "I" would like to welcome all of you to Bali-a world renowned island, rich in culture, tradition and history, (6) "I" therefore commend the Indonesian Organizing Committee, together with the OGP Steering Committee and the OGP Support Unit, for convening this important Conference and (8) "I" can see among us representatives of governments, regional and international organizations, civil society organizations, academia, youth, private sector, and the media. It indicates that SBY wants to invite all governments sector, Indonesian people and another contries to build up their country each other. It can be concluded that speech function has role in delivering meaning of the text.

Speech function is initiated by the speaker. The speech function by an addresser is responded by addressee. In this case, the reasons for the dominant speech function are as follow: (1) The information given is up to date to be discussed, (2) The writer wants to show their one way communication to describe the character of the politicans and (3) To attract the readers' attention to read the SBY's speeches. Leckie-Tarry (1995:36) that the field of text is constitued by three features of arena or social activity, participant's characteristics and semantic domain. Thus, there are varieties of sounds, lexical items and lexicogrammar as varieties of language with respects to the factors of arena or social activities, participants' characteristics and semantic domain.

Meanwhile, the context of situation in this stucy concerned to the field and dominated by arena or social activity refers to the location where social activities were performed, especially [+institutionalized]. The feature of [+institutionalized] means that social activities are regulated or governed by a certain insitution whereas that [institutionalized] refers to social activities which are free from institutional influence or authority. It means that an activity is conducted or constrained by institutional rules, namely Asia Pacific Regional Conference of Open Government Partnership (OGP).

\section{CONCLUSIONS}

This thesis has been analyzed by applying experiential function analysis. The researcher presents some valuable conclusions. (1.a) There are six (6) types of process in experiential function; material, mental, relational, behavioural, verbal and existential process.

Based on analysis and findings, the SBY's speech at the Asia Pacific Regional Conference of Open 
Government Partnership in 2014, there were five (5) processes that formed the patterns of representation of experience namely; material, mental, relational, verbal and existential. (1.b) Material is the most dominant patterns in SBY's speech at the Asia Pacific Regional Conference of Open Government Partnership in 2014. It means that material process is known as process of doing. It deals with the notion that some entity 'does' something which may be done 'to' some other entity. (2) There are nine types of circumtances found in the speech, namely extent, location, manner, cause, contingency, accompaniment, role, matter and angle. The most dominant circumtance appeared is circumtance of manner with total number 28 circumtances, while less circumtance is matter. (3) Context of situation related to the field in this study.

Field stand for three entries, namely arena [+institutionalized/institutionalized], participant's characteristics [personal/social] and semantic domain [+specialized/specialized]. The most dominant entry appeared in the speech were arena, especially [ +instituionalized]. It means that an activity is conducted or constrained by institutional rules, which the context refers to the political issue.

\section{REFERENCES}

Ary, D., Jacobs, LC., Sorensen, C., and Razavieh, A. 2010. Introduction to Research in Education, 8th Edition. USA: Wadsworth.

Beard, A. 2000. The Language of Politics. Florence, USA: Routledge.

Batubara, L.S. 2011. Ideational Function in Motivational Speech of Martin Luther King Jr. "I Have a Dream" and Winston Churcill "Blood Toil Tears and Sweat" Unpublished Thesis, Postgraduate School, Universitas Negeri Medan (UNIMED), Medan.

Bodgan, R.C., and Biklen, S.K. 1992. Qualitative Research for Education: An Introduction to Theory and Method (2nd Edition). Sydney, Allyn and Bacon.

Christie, and Martin, J.R. 1997. Genre and Institutions: Social Process in the Workplace and School. London: Cassel.

Collerson, J. 1994. English Grammar: A Functional Approach. Victoria: Primary English Teaching Association.

Denzin, N. K. and Lincoln, Y.S. 1994. Handbook of Qualitative Research (2nd ed). Thousand Oaks, CA: Sage Publications.

Dwi. S, W. 2010. Ideational Meaning and Thematic Analysis on Childrens' Songs in Barney "Dancing and Singing" Series. Unpublished Thesis, Universitas Diponegoro (UNDIP), Semarang.

Eggins, S. and Martin, J.R. 1994. An Introduction to Systemic Functional Linguistics. London: Pinter.

Fairclough, N. 1992. Discourse and Social Change. Oxford: Polity Press. 
Gurning, B. 2005. Penggunaan Bahasa Inggris dalam Teks Ilmu-Ilmu Alam dan Ilmu-Ilmu Sosial. Disertasi Pascasarjana, Universitas Negeri Jakarta.

Halliday, M.A.K..1973. Explorations in the Functions of Language. London: Edward Arnold.

Halliday, M.A.K. 1994. An Introduction of Functional Grammar-Second Edition. London: Edward Arnold.

Halliday, M.A.K.. 1994. Functional Grammar. 2nd Edition. London: Edward Arnold.

Halliday, M.A.K.. 1985. Spoken and Written Language. Oxford: Oxford University Press.

Halliday and Hasan (1989) Language, Context and Text: Aspects of language in a social-semiotic perspective. Oxford, OUP.

Halliday, M.A.K and C.M.I.M. 1999. Matthiessen Construing Experience Through Meaning: A Language-Based Approach to Cognition. London: Continuum.

Halliday, M.A.K.. 2007. Language and Education. London: Continuum.

Liping, C. 2014. Experiential Metafunctional Analysis of Winston S. Churchill's Speech on Hitler's Invasion of the U.S.S.R. School of Foreign Languages, Guangdong University of Petrochemical Technology, Guangdong, China. English Language Teaching; Vol. 7, No. 9; 2014 ISSN 1916-4742 E-ISSN 1916-4750. Published by Canadian Center of Science and Education.

Metasari, D. 2013. Appraisal System in the Jakarta Post's Editorial "Start Working, Jokowi". Semarang. Unpublished Thesis,
Universitas Dian Nuswantoro (UDINUS), Semarang.

Nur, S. 2015. Analysis of Interpersonal Metafunction in Public Speeches: A Case Study of Nelson Mandela's Presidential Inauguration Speech. King Khalid University, Saudi Arabia.

Rahmah, Sinar, T.S., Mbete, A.M., Setia, E. 2015. Ideational Meaning of Wedding Ceremony in Deli Malay's Traditional Culture: A Multimodal Analysis. Dept. of Linguistics, Postgraduate School, University of Sumatera Utara (Indonesia). IOSR Journal of Humanities and Social Science (IOSR-JHSS) Volume 20, Issue 2, Ver. 1 (Feb. 2015), PP 22-29 eISSN: 2279-0837, p-ISSN: 22790845. www.iosrjournals.org.

Ramelan, M. 1985. Morfologi. Yogyakarta. CV. Karyono.

Rambe. 2015. The Experiential Meaning in Batak Angkola Wedding Ceremony. Unpublished Thesis, Postgraduate School, Universitas Negeri Medan (UNIMED), Medan.

Saragih, A. 2012. Discourse Analysis: A Systemic Functional Linguistic Approach to the Analysis of Discourse and Texts. Lecture Material, Universitas Negeri Medan (UNIMED), Medan.

Saragih, A. 2013. Lecture on Systemic Functional Linguistics. Medan. Unpublished Thesis, Universitas Sumatra Utara (USU). Postgraduate School of Linguistics.

Saragih, A. 2014. Variations and Functional Varieties of Language. Lecture Material, Universitas Negeri Medan (UNIMED), Medan.

Vol.3 No. 2 Juli- Desember 2018/97 
Shenton, A. and Hayters, S. 2014.

Strategies for Gaining Access to

Organizations and Informans in

Qualitative Studies. Education for

Information, 22, 223-231.

Sidabutar, U. 2014. Modality on the Delegation Speech of APEC Conference 2013. Unpublished Thesis, Postgraduate School, Universitas Negeri Medan (UNIMED), Medan.

Surur, A. 2013. Experiential Function in Barack Obama's Speech on General Election Campaign of 2012. Unpublished Thesis, Postgraduate School, Universitas Negeri Medan (UNIMED), Medan.

White, P.R. 1998. Telling Media Tales: the News Story As Rhetoric. Ph.D Unpublished Dissertation, University of Sydney, Sydney. 